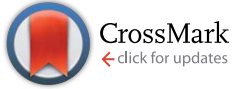

Cite this: RSC Adv., 2016, 6, 51834

\title{
Atmospheric sink of methyl chlorodifluoroacetate and ethyl chlorodifluoroacetate: temperature dependent rate coefficients, product distribution of their reactions with $\mathrm{Cl}$ atoms and $\mathrm{CF}_{2} \mathrm{ClC}(\mathrm{O}) \mathrm{OH}$ formation $\uparrow$
}

\begin{abstract}
María B. Blanco, ${ }^{a}$ Ian Barnes, ${ }^{b}$ Peter Wiesen ${ }^{b}$ and Mariano A. Teruel ${ }^{\star a}$
Rate coefficients as a function of temperature have been measured for the first time for the gas-phase reactions of chlorine atoms with methyl chlorodifluoracetate $\left(k_{1}\right)$ and ethyl chlorodifluoroacetate $\left(k_{2}\right)$ using the relative rate technique. The experiments were carried out in a $1080 \mathrm{~L}$ photoreactor over the temperature range $287-313 \mathrm{~K}$ at a total pressure of $1000 \pm 10 \mathrm{mbar}$ of synthetic air using in situ FTIR spectroscopy to monitor reactants and products. The following Arrhenius expressions were obtained: $k_{(\mathrm{MCDFA}+\mathrm{Cl})}=(9.6 \pm 5.1) \times 10^{-12} \exp [-(1363 \pm 79) / T]$ and $k_{(\mathrm{ECDFA}+\mathrm{Cl})}=(64.4 \pm 29.7) \times 10^{-12} \exp$ $[-(1110 \pm 68) / T]$. The kinetic results are compared with previous experimental and theoretical studies. In addition, a product study of the reactions of $\mathrm{Cl}$ with methyl chlorodifluoracetate and ethyl chlorodifluoroacetate is reported. The results indicate that in the absence of $\mathrm{NO}_{x}$ the main fate of the alkoxy radicals formed after $\mathrm{H}$-atom abstraction by $\mathrm{Cl}$ from the $-\mathrm{CH}_{3}$ group in methyl chlorodifluoroacetate is reaction of the radical with $\mathrm{O}_{2}$ to form the mixed anhydride $\mathrm{CF}_{2} \mathrm{ClC}(\mathrm{O}) \mathrm{OC}(\mathrm{O}) \mathrm{H}$. In the case of ethyl chlorodifluoroacetate the main fate of the alkoxy formed via $\mathrm{H}$-atom abstraction by $\mathrm{Cl}$ from the $-\mathrm{CH}_{2}$ - entity in the ethyl group is $\alpha$-ester rearrangement to produce chlorodifluoroacetic acid and the corresponding radical. The yields of chlorofluoracetic acid $\left(\mathrm{CF}_{2} \mathrm{ClC}(\mathrm{O}) \mathrm{OH}\right)$ obtained were as follows: $(34 \pm 5) \%$ and $(86 \pm 8) \%$ for the reactions of $\mathrm{Cl}$ with $\mathrm{CF}_{2} \mathrm{ClC}(\mathrm{O}) \mathrm{OCH}_{3}$ and $\mathrm{CF}_{2} \mathrm{ClC}(\mathrm{O}) \mathrm{OCH}_{2} \mathrm{CH}_{3}$, respectively. The measured yields are rationalized in terms of mechanisms consisting of competitive reaction channels for the formed products in the oxidation, i.e. reaction with $\mathrm{O}_{2}, \alpha$-ester rearrangement and a decomposition pathway. Atmospheric implications are discussed according to the rate coefficients obtained as a function of temperature and altitude, and regarding the formation of chlorofluorocarboxylic acid.
\end{abstract}

Received 5th February 2016 Accepted 17th May 2016

DOI: $10.1039 / \mathrm{c} 6 \mathrm{ra03454c}$

www.rsc.org/advances

\section{Introduction}

Oxygenated Volatile Organic Compounds (OVOCs) such as hydrofluoroethers (HFEs) and hydrochlorofluoroethers (HCFEs) have an oxygen linkage which makes the hydrogen atoms of the ether molecule more labile and increases their reactivity toward $\mathrm{OH}$ radicals and $\mathrm{Cl}$ atoms in the lower atmosphere compared to chlorofluorocarbons (CFCs) and hydrochlorofluorocarbons (HCFCs). This increased atmospheric photooxidation potential of HFEs and HCFEs over CFCs and HCFCs makes them good

${ }^{a}$ CONICET, Instituto de Investigaciones en Fisicoquimica, I.N.F.I.Q.C., Facultad de Ciencias Quimicas, Universidad Nacional de Córdoba, Ciudad Universitaria, 5000 Córdoba, Argentina. E-mail: mteruel@fcq.unc.edu.ar; Fax: +54-351-4334188

${ }^{b}$ Bergische Universität Wuppertal, Fakultät für Mathematik und Naturwissenschaften, Physikalische \& Theoretische Chemie, Gauss Strasse 20, 42119 Wuppertal, Germany $\dagger$ Electronic supplementary information (ESI) available. See DOI: 10.1039/c6ra03454c replacement materials in many applications such as solvents, heat-transfer fluids in refrigeration systems, cleaning agents in the electronic industry, foam-blowing, lubricant deposition, and dry etching agents and as anesthetics., ${ }^{1,2}$

The hydroxyl radical $(\mathrm{OH})$ is the primary cleaning agent of the lower atmosphere and is thus the dominant sink for many greenhouse gases and pollutants. In coastal and marine regions and in inland areas near to pollutant sources the concentration of $\mathrm{Cl}$ can attain concentration levels which make reactions with Volatile Organic Compounds (VOCs) competitive with the $\mathrm{OH}-$ radical initiated degradation of these VOCs. ${ }^{3-6}$ In recent years, evidence has been presented for Cl-atom chemistry in continental regions far removed from coastal and marine regions where observations of $\mathrm{Cl}$-atom precursors, have been made..$^{7-10}$ Additionally, urban sources of $\mathrm{Cl}$ atoms due to industrial activities can exist, and $\mathrm{Cl}$ concentrations higher than the concentration levels observed in marine regions have been reported, for example, in the vicinity of ceramic industries. ${ }^{11}$ 
Chlorinated fluoroesters (CFESs) are emitted to the atmosphere mainly by anthropogenic sources. Methyl chlorodifluoroacetate (MCDFA) is used as a building block in organic synthesis $^{\mathbf{1 2}}$ and ethyl chlorodifluoroacetate (ECDFA) is employed extensively in fire retardants and also finds use in the production of pesticides, dyestuffs, phosphates and medicine. ${ }^{13}$

MCDFA and ECDFA can be produced directly in the troposphere through the photooxidation of hydrochlorofluoroethers analogous to the formation of fluoroesters from HFEs. ${ }^{14,15}$ In order to evaluate if HCFEs are environmentally acceptable replacements for CFCs and HCFCs, rate coefficients and product distributions for the reactions of the CFESs with the main tropospheric oxidants are necessary.

Hence, as part of a systematic study on the kinetics and oxidation products of the atmospheric reactions of haloesters, we report in this work, rate coefficients for the reactions of $\mathrm{Cl}$ atoms with methyl chlorodifluoroacetate and ethyl chlorodifluoracetate measured over the temperature range $287-313 \mathrm{~K}$ using a relative kinetic technique:

$$
\begin{gathered}
\mathrm{ClCF}_{2} \mathrm{C}(\mathrm{O}) \mathrm{OCH}_{3}+\mathrm{Cl} \rightarrow \text { products } \\
\mathrm{ClCF}_{2} \mathrm{C}(\mathrm{O}) \mathrm{OCH}_{2} \mathrm{CH}_{3}+\mathrm{Cl} \rightarrow \text { products }
\end{gathered}
$$

This study extends our previous kinetic database for the title reactions at $298 \mathrm{~K}^{\mathbf{1 6}}$ through provision of the temperature dependence for the reactions.

To the best of our knowledge, the temperature dependence of the reactions has not been previously reported. Although, there are many kinetic and mechanistic studies of the reactions of $\mathrm{Cl}$ atoms with a variety of hydrogenated esters, the database for haloesters is very limited. Furthermore, there is no information available on the degradation mechanisms of chlorofluorinated esters in the atmosphere and the resulting products.

Therefore, the main reaction products of the haloesters have been identified and their yields quantified. This information has been used to propose atmospheric degradation mechanisms for the Cl-atom mediated oxidation of the compounds. Formation of chlorodifluoracetic acid has been observed in high yields. Field measurements of the acid in precipitation suggest that it may accumulate in the aquatic enviroment. ${ }^{17}$

The aim of the present work is to determine the fate of the chlorofluoroalkoxy radical formed in the Cl-initiated photodegradation of the chlorofluoroacetates studied, and appraise its possible contribution to the accumulation in the environment of chlorofluorinated compounds such as chlorodifluoracetic acid (CDFA).

\section{Experimental}

The experiments were performed in a $1080 \mathrm{~L}$ photoreactor a detailed description of which can be found elsewhere thus only a brief general overall description is given here. ${ }^{18} \mathrm{~A}$ diagram of the reactor is presented below (Scheme 1). The reactor has a total length of $6.2 \mathrm{~m}$ and an internal diameter of $0.47 \mathrm{~m}$, it consists of two quartz glass cylinders which are connected by a central enamel flange ring and silicon rubber seals and is closed at both ends by aluminum flanges which contain inlet ports for reactants etc. The reactor can be temperature regulated within the range 287 to $313 \mathrm{~K}$ with a precision of $\pm 2 \mathrm{~K}$ through a regulation system using three PT-100 thermo-elements. The chamber can be evacuated by a pumping system consisting of a turbo-molecular pump backed by a double stage rotary fore pump to $10^{-3}$ Torr. The photolysis system consists of 32 superactinic fluorescent lamps (Philips TL05 $40 \mathrm{~W}$ ), which are evenly spaced around the reaction vessel. The lamps emit light with a maximum intensity at $360 \mathrm{~nm}$. The chamber is equipped with a White type multiplereflection mirror system for sensitive in situ long path absorption monitoring of reactants and products in the IR spectral range $4000-700 \mathrm{~cm}^{-1}$ and was operated at total optical path length of $484.7 \pm 0.8 \mathrm{~m}$. IR spectra were recorded with a spectral resolution of $1 \mathrm{~cm}^{-1}$ using a Nicolet Nexus FT-IR spectrometer equipped with a $\mathrm{KBr}$ beam splitter and a liquid nitrogen cooled mercury-cadmium-telluride (MCT) detector.

The rate coefficients for the reaction of $\mathrm{Cl}$ atoms with the chlorofluoroacetates were determined using the relative kinetic technique. Chlorine atoms were generated by photolysis of molecular $\mathrm{Cl}_{2}$ :

$$
\mathrm{Cl}_{2}+h \nu \rightarrow 2 \mathrm{Cl}
$$

In the presence of $\mathrm{Cl}$ atoms, the chlorofluoroacetates and the reference compounds decay through the following reactions:

$$
\begin{gathered}
\mathrm{Cl}+\text { chlorofluoroacetate } \rightarrow \text { products, } k_{\text {chlorofluoroacetate }} \\
\mathrm{Cl}+\text { reference } \rightarrow \text { products, } k_{\text {reference }}
\end{gathered}
$$

Provided that the reference compound and the reactant are lost only by reactions (4) and (5), then it can be shown that:

$$
\ln \left\{\frac{[\text { chlorofluoroacetate }]_{0}}{[\text { chlorofluoroacetate }]_{t}}\right\}=\frac{k_{\text {chlorofluoroacetate }}}{k_{\text {reference }}} \ln \left\{\frac{[\text { reference }]_{0}}{[\text { reference }]_{t}}\right\}
$$

where, $[\text { chlorofluoroacetate }]_{0}$, $[\text { reference }]_{0}$, [chlorofluoroacetate $]_{t}$ and $[\text { reference }]_{t}$ are the concentrations of the halogenated esters and reference compound at times $t=0$ and $t$, respectively and $k_{\text {chlorofluoroacetate }}$ and $k_{\text {reference }}$ are the rate coefficients of reactions (4) and (5), respectively.

The relative rate technique relies on the assumption that both the chlorofluoroacetates and reference organics are removed solely by reaction with $\mathrm{Cl}$ atoms. To verify this assumption, mixtures of chlorine and both organics (chlorofluoroacetate and reference hydrocarbon) in air were prepared and allowed to stand in the dark for 30 minutes the typical duration of an experiment. In all cases, reaction of the organic species with the Cl-atom precursor $\mathrm{Cl}_{2}$ in the absence of $\mathrm{UV}$ light was of negligible over this time period. Additionally, to test for possible photolysis of the reactants mixtures of the chlorofluoroesters and reference compounds in air in the absence of molecular chlorine were irradiated using the output from all the fluorescent lamps surroundings the chamber for $30 \mathrm{~min}$. Photolysis was not observed for any of the reactants. 


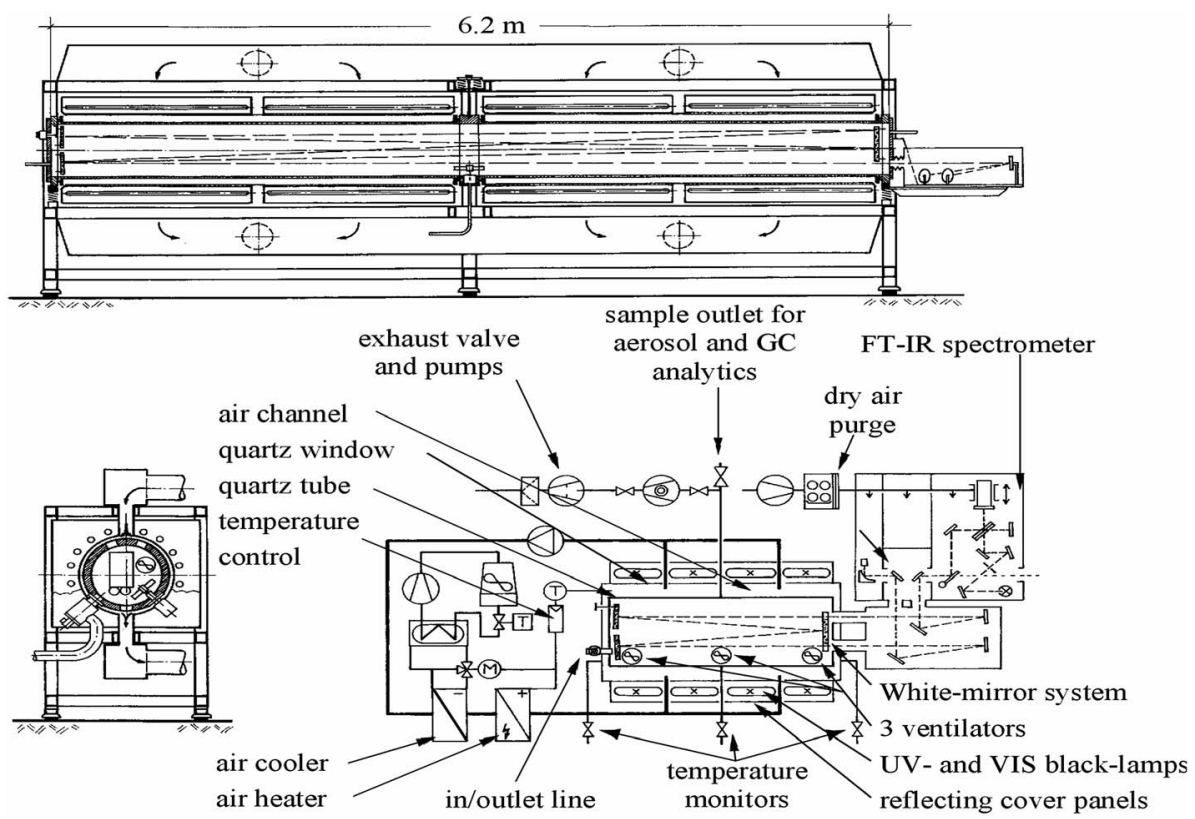

Scheme 1 Schematic diagram of the $1080 \mathrm{~L}$ quartz-glass reactor.

For the kinetic investigations chloromethane was used as the reference compound and experiments were performed on $\mathrm{Cl}_{2}$ /chlorofluoroester/chloromethane/air mixtures which were irradiated for periods of 15-20 minutes during the course of which infrared spectra were recorded with the FTIR spectrometer. Typically 64 interferograms were co-added per spectrum over a period of approximately 1 minute. Similar experiments were performed for the product studies without the reference compound in the reaction mixtures.

\section{Results and discussion}

\section{Temperature dependence of the reactions of $\mathrm{Cl}$ atoms with MCDFA and ECDFA}

Rate coefficients for the reactions of $\mathrm{Cl}$ atoms with MCDFA and ECDFA were determined at atmospheric pressure over the temperature range of $287-313 \mathrm{~K}$ relative to the reaction of $\mathrm{Cl}$ atoms with chloromethane. Fig. $\mathrm{S} 1$ and $\mathrm{S} 2 \uparrow$ show examples of the kinetic data obtained at three temperatures (287, 303 and $313 \mathrm{~K}$ ) for both methyl chlorodifluoroacetate and ethyl chlorodifluoroacetate plotted according to eqn (I). The rate coefficient ratios $k_{\mathrm{CFES}} / k_{\text {reference }}$ obtained from linear least squares analyses of such plots are listed in Table 1 . The rate coefficient ratios are each from a minimum of at least three or four experiments for each temperature and CFES and the errors are the $2 \sigma$ statistical errors from the linear regression analyses.

The rate coefficients for the reaction of $\mathrm{Cl}$ atoms with the chlorofluoroacetates listed in Table 1 have been put on an absolute basis using rate coefficients for $\mathrm{Cl}$ with chloromethane at the respective temperatures calculated from the following Arrhenius expression (with $k$ in $\mathrm{cm}^{3}$ per molecule per s units):

$k(\mathrm{Cl}+$ chloromethane $)=3.3 \times 10^{-11} \mathrm{e}^{-(1250) / T} \mathrm{~cm}^{3}$ per molecule per s. ${ }^{19}$

Table 1 Temperature dependent rate coefficient ratios, $k_{\mathrm{CFES}} / k_{\text {reference, }}$ and rate coefficients, $k_{\mathrm{CFES}}$, and the resulting Arrhenius parameters for the gas-phase reactions of $\mathrm{Cl}$ atoms with methyl chlorodifluoroacetate (MCDFA) and ethyl chlorodifluoroacetate (ECDFA)

\begin{tabular}{|c|c|c|c|c|c|}
\hline$T(\mathrm{~K})$ & $k_{\mathrm{CFES}} / k_{\text {reference }}$ & $\begin{array}{l}k_{\mathrm{CFES}} \times 10^{13} \\
\left(\mathrm{~cm}^{3} \text { per molecule per } \mathrm{s}\right)\end{array}$ & CFES & $E_{\mathrm{a}} / R(\mathrm{~K})$ & $\begin{array}{l}A \times 10^{12} \\
\left(\mathrm{~cm}^{3} \text { per mo }\right.\end{array}$ \\
\hline & & & Methyl chlorodifluoroacetate & & \\
\hline 287 & $0.19 \pm 0.01$ & $0.83 \pm 0.36$ & & & \\
\hline 294 & $0.20 \pm 0.02$ & $0.93 \pm 0.41$ & & & \\
\hline 298 & $0.20 \pm 0.01$ & $0.98 \pm 0.44$ & & $1363 \pm 79$ & $9.6 \pm 5.1$ \\
\hline 303 & $0.20 \pm 0.02$ & $1.12 \pm 0.49$ & & & \\
\hline 313 & $0.21 \pm 0.02$ & $1.24 \pm 0.52$ & & & \\
\hline 287 & $3.14 \pm 0.05$ & $13.53 \pm 4.36$ & Ethyl chlorodifluoroacetate & & \\
\hline 294 & $3.08 \pm 0.04$ & $14.29 \pm 4.38$ & & & \\
\hline 298 & $3.13 \pm 0.04$ & $15.59 \pm 4.43$ & & $1110 \pm 68$ & $64.4 \pm 29.7$ \\
\hline 303 & $3.12 \pm 0.03$ & $17.10 \pm 4.52$ & & & \\
\hline 313 & $3.06 \pm 0.04$ & $18.64 \pm 4.69$ & & & \\
\hline
\end{tabular}


The errors given for the rate coefficients are a combination of the $2 \sigma$ statistical errors from the linear regression analyses plus an added uncertainty to take into account the error associated with the values of the reference rate coefficients.

The values of the rate coefficients for the reactions of $\mathrm{Cl}$ atoms with methyl chlorodifluoroacetate and ethyl chlorodifluoroacetate as a function of temperature are plotted in Arrhenius form in Fig. 1. Linear least-squares analysis of the plots leads to the following Arrhenius expressions in units of $\mathrm{cm}^{3}$ per molecule per s:

$$
\begin{aligned}
& k_{(\mathrm{MCDFA}+\mathrm{Cl})}=(9.6 \pm 5.1) \times 10^{-12} \exp [-(1363 \pm 79) / T] \\
& k_{(\mathrm{ECDFA}+\mathrm{Cl})}=(64.4 \pm 29.7) \times 10^{-12} \exp [-(1110 \pm 68) / T]
\end{aligned}
$$

The errors in the activation term and the pre-exponential factor are the $2 \sigma$ random statistical errors from fits to the data presented in Table 1 and plotted in Fig. 1 (panels a and b). To
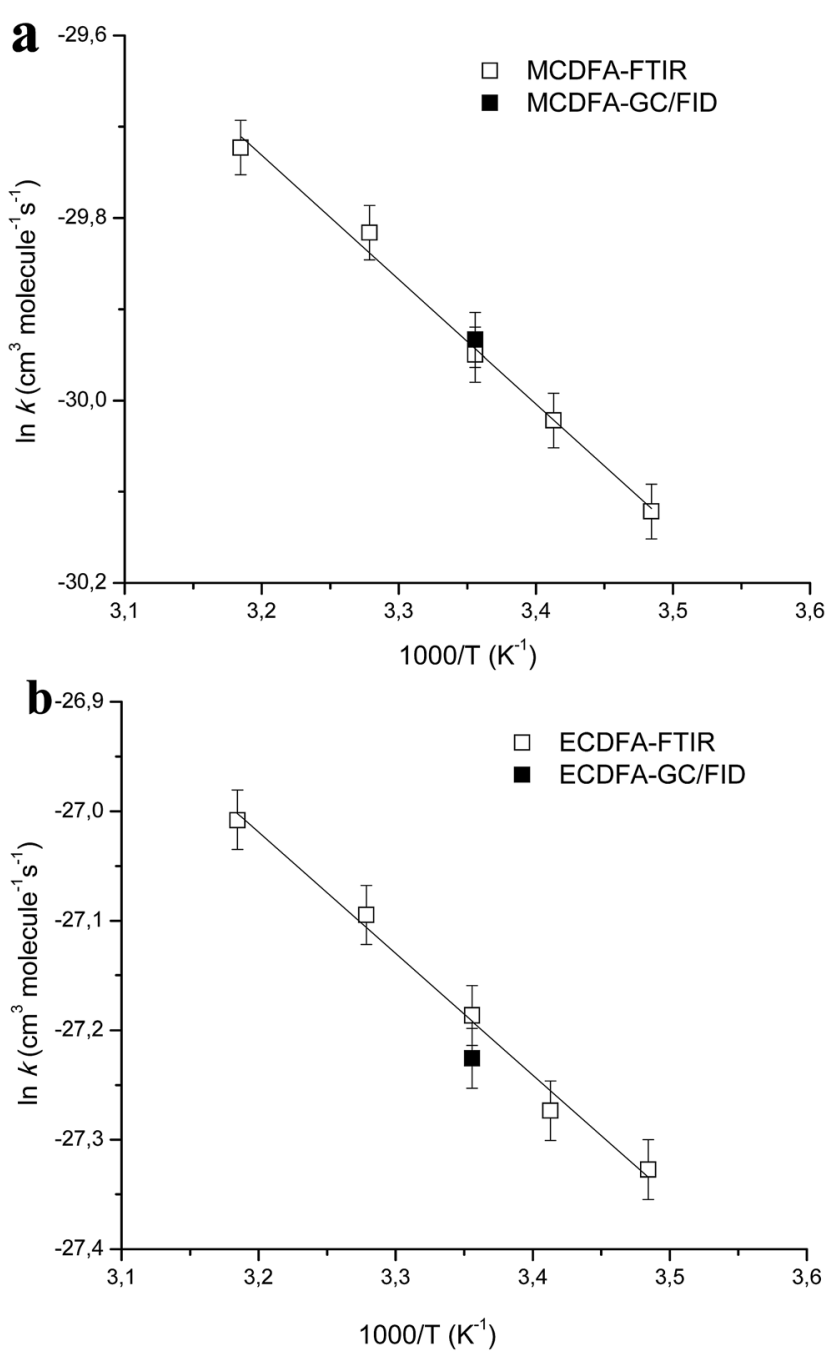

Fig. 1 Arrhenius plots of the temperature dependent kinetic data obtained for the reactions of $\mathrm{Cl}$ atoms with MCDFA (a) and ECDFA (b) in the present study. For comparison, the room temperature rate coefficient from our previous work ${ }^{16}$ is also shown (filled symbol). the best of our knowledge there are no prior experimental determinations of the Arrhenius parameters for these reactions, hence, this study represents the first temperature dependence study of the reactions of $\mathrm{Cl}$ atoms with MCDFA and ECDFA.

The positive $E_{\mathrm{a}} / R$ values of $(1363 \pm 79) \mathrm{K}$ and $(1110 \pm 68) \mathrm{K}$ for the reaction of $\mathrm{Cl}$ atoms with MCDFA and ECDFA, respectively, indicates the dominance of a hydrogen abstraction pathway under the experimental conditions i.e. the rate coefficients increase slightly with temperature.

The $E_{\mathrm{a}} / R$ values of $1363 \mathrm{~K}$ and $1110 \mathrm{~K}$ reported in this work for the reactions of MCDFA $+\mathrm{Cl}$ and ECDFA $+\mathrm{Cl}$, respectively are consistent with the available $E_{\mathrm{a}} / R$ literature data for the reactions of $\mathrm{Cl}$ atoms with hydrofluoroethers and fluoroesters where $E_{\mathrm{a}} / R$ values of $852,1190,2254,968,1216,1637$ and $1368 \mathrm{~K}$ have been reported for the reactions of $\mathrm{Cl}$ atoms with HFE-7200 $\left(\mathrm{C}_{4} \mathrm{~F}_{9} \mathrm{OC}_{2} \mathrm{H}_{5}\right)$, HFE-7500 $\left(n-\mathrm{C}_{3} \mathrm{~F}_{7} \mathrm{CF}\left(\mathrm{OC}_{2} \mathrm{H}_{5}\right) \mathrm{CF}\left(\mathrm{CF}_{3}\right)_{2}\right)$, HFE-7100 $\left(\mathrm{C}_{4} \mathrm{~F}_{9} \mathrm{OCH}_{3}\right), \quad$ HFE-7300 $\left(n-\mathrm{C}_{2} \mathrm{~F}_{5} \mathrm{CF}\left(\mathrm{OCH}_{3}\right) \mathrm{CF}\left(\mathrm{CF}_{3}\right)_{2}\right), \quad \mathrm{CF}{ }_{3} \mathrm{C}(\mathrm{O})$ $\mathrm{OCH}_{3}, \mathrm{CF}_{3} \mathrm{C}(\mathrm{O}) \mathrm{OCH}_{2} \mathrm{CH}_{3}$ and $\mathrm{CF}_{2} \mathrm{HC}(\mathrm{O}) \mathrm{OCH}_{3}$, respectively. ${ }^{20-23}$ The employment of temperature dependent kinetic data in model calculations increases the accuracy of the models since the temperature gradient of the troposphere and the seasonal temperature variations can be taken into consideration.

\section{Comparison with previous kinetic determinations}

The following rate coefficients have been obtained at $298 \mathrm{~K}$ for the reaction of $\mathrm{Cl}$ with MCDFA and ECDFA:

$$
\begin{aligned}
& k_{1}=(0.98 \pm 0.44) \times 10^{-13} \mathrm{~cm}^{3} \text { per molecule per } \mathrm{s} \\
& k_{2}=(15.55 \pm 4.43) \times 10^{-13} \mathrm{~cm}^{3} \text { per molecule per } \mathrm{s}
\end{aligned}
$$

The values of $k_{1}$ and $k_{2}$ at room temperature are in very good agreement with our previously reported values ${ }^{16}$ of $k_{(\mathrm{Cl}+\mathrm{MCDFA})}=$ $(1.0 \pm 0.2) \times 10^{-13}$ and $k_{(\mathrm{Cl}+\mathrm{ECDFA})}=(15 \pm 3) \times 10^{-13} \mathrm{~cm}^{3}$ per molecule per $\mathrm{s}^{16}$ obtained at $298 \mathrm{~K}$ and 750 Torr total pressure in a 80 liter Teflon bag using the relative kinetic method with gas chromatography/flame ionization detection (RR-GC/FID) for the analyses. These two measurements are represented in Fig. 1 by filled symbols, for the reaction of $\mathrm{Cl}$ with MCDFA (Fig. 1a) and ECDFA (Fig. 1b), respectively. Mishra et al. ${ }^{24}$ have calculated the rate coefficient for $\mathrm{H}$-atom abstraction from $\mathrm{CF}_{2} \mathrm{ClC}(\mathrm{O}) \mathrm{OCH}_{3}$ by $\mathrm{Cl}$ atoms using canonical transition state theory (CTST) and employing Wigner ${ }^{25}$ and Eckart ${ }^{26}$ symmetrical methods which gave values of $0.96 \times 10^{-13}$ and $1.20 \times 10^{-13} \mathrm{~cm}^{3}$ per molecule per s, respectively, at $298 \mathrm{~K}$ for the reaction. These values are in very good agreement with the experimental value of $0.98 \times$ $10^{-13} \mathrm{~cm}^{3}$ per molecule per s reported in this work and the previous experimental value reported by our group, using a different experimental setup, of $(1.0 \pm 0.2) \times 10^{-13} \mathrm{~cm}^{3}$ per molecule per $\mathrm{s}^{19}$

In another study Mishra et $a .^{27}$ have reported rate coefficients for $\mathrm{H}$-atom abstraction from the ethyl group in $\mathrm{CF}_{2} \mathrm{ClC}(\mathrm{O})$ $\mathrm{OCH}_{2} \mathrm{CH}_{3}$ by $\mathrm{Cl}$ atoms at $298 \mathrm{~K}$. They reported rate coefficients of $3.88 \times 10^{-14}$ and $1.82 \times 10^{-12} \mathrm{~cm}^{3}$ per molecule per $\mathrm{s}$ for the reaction channels $\mathrm{CF}_{2} \mathrm{ClC}(\mathrm{O}) \mathrm{OCH}_{2} \mathrm{CH}_{3}+\mathrm{Cl} \rightarrow \mathrm{CF}_{2} \mathrm{ClC}(\mathrm{O})$ $\mathrm{OCH}_{2} \mathrm{CH}_{2}+\mathrm{HCl}$ and $\mathrm{CF}_{2} \mathrm{ClC}(\mathrm{O}) \mathrm{OCH}_{2} \mathrm{CH}_{3}+\mathrm{Cl} \rightarrow \mathrm{CF}_{2} \mathrm{ClC}(\mathrm{O})$ 
$\mathrm{OCHCH}_{3}+\mathrm{HCl}$, respectively. Mishra et al. ${ }^{27}$ reported a value of $1.86 \times 10^{-12} \mathrm{~cm}^{3}$ per molecule per $\mathrm{s}$ for the overall rate coefficient of the reaction (i.e. the sum of the rate coefficients for each reaction channel) which is in very good agreement with our previous experimental value of $(1.5 \pm 0.3) \times 10^{-13} \mathrm{~cm}^{3}$ per molecule per $\mathrm{s}^{16}$ and the rate coefficient of $(1.55 \pm 0.44) \times 10^{-13}$ $\mathrm{cm}^{3}$ per molecule per s reported in this work.

The $\mathrm{RC}(\mathrm{O}) \mathrm{O}$ - group is known to have a deactivating effect on $\mathrm{C}-\mathrm{H}$ bonds positioned both $\alpha$ and also $\beta$ to the group. ${ }^{28} \mathrm{It}$ is interesting to compare the rate coefficients for $\mathrm{Cl}$ with the two chlorodifluoroesters with those of methyl acetate (MA) and ethyl acetate (EA). The reactions of $\mathrm{Cl}$ with MA and EA have rate coefficients of $2.2 \times 10^{-12}$ and $1.76 \times 10^{-11} \mathrm{~cm}^{3}$ per molecule per s, respectively, whereby the contribution from $\mathrm{H}$-atom abstraction from the acetyl group $\mathrm{CH}_{3} \mathrm{C}(\mathrm{O}) \mathrm{O}$ is $<1 \times$ $10^{-13} .^{28}$ The rate coefficients for the reactions of $\mathrm{Cl}$ atoms with MCDFA and ECDFA are factors of approximately 22 and 11 slower than those of $\mathrm{Cl}$ with MA and EA, respectively, indicating the strong deactivating effect of the $\mathrm{ClF}_{2} \mathrm{C}$ - group on the reactivity of the chlorodifluoroesters toward $\mathrm{Cl}$. It is also interesting to note when comparing rate coefficients for halogenated esters ${ }^{23}$ that $k\left(\mathrm{Cl}+\mathrm{ClF}_{2} \mathrm{CC}(\mathrm{O}) \mathrm{OCH}_{3}\right)>k(\mathrm{Cl}+$ $\left.\mathrm{F}_{3} \mathrm{CC}(\mathrm{O}) \mathrm{OCH}_{3}\right)$ and $k\left(\mathrm{Cl}+\mathrm{ClF}_{2} \mathrm{CC}(\mathrm{O}) \mathrm{OCH}_{2} \mathrm{CH}_{3}\right)>k(\mathrm{Cl}+$ $\left.\mathrm{F}_{3} \mathrm{CC}(\mathrm{O}) \mathrm{OCH}_{2} \mathrm{CH}_{3}\right)$ supporting an expected stronger negative inductive effect for $\mathrm{F}_{3} \mathrm{C}$ - over $\mathrm{ClF}_{2} \mathrm{C}$-.

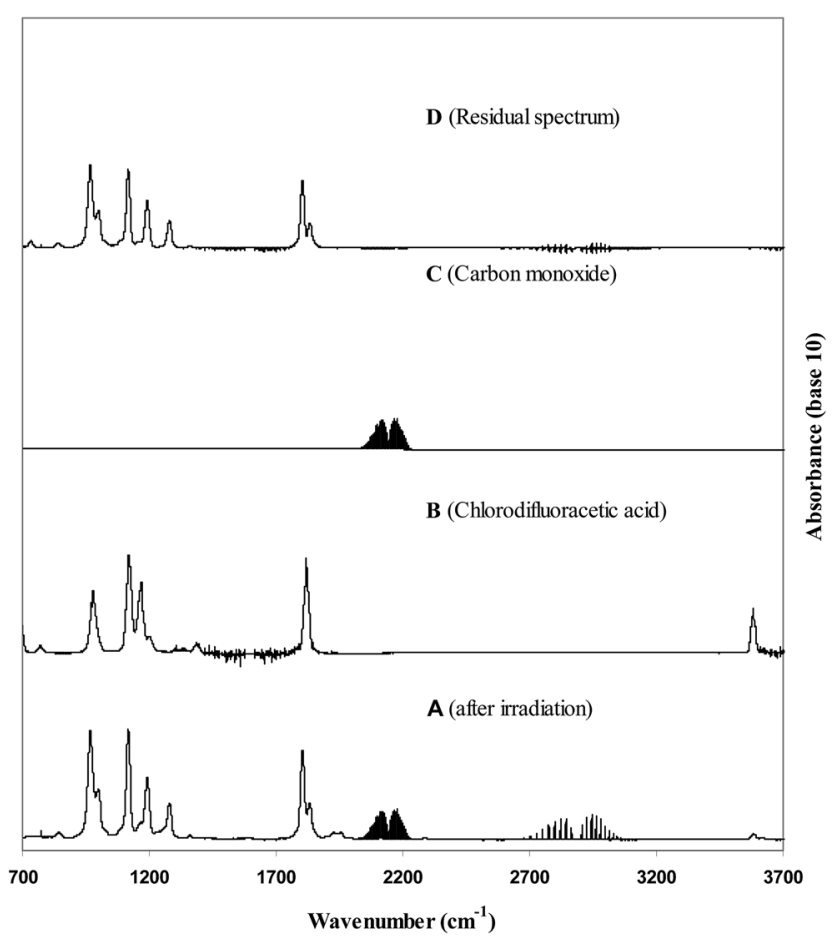

Fig. 2 Trace (A) shows the infrared spectrum of a $M C D F A / C_{2} /$ air reaction mixture after irradiation and subtraction of residual methyl chlorodifluoroacetate. Trace (B) shows a reference spectra of chlorodifluoroacetic acid $\left(\mathrm{CF}_{2} \mathrm{ClC}(\mathrm{O}) \mathrm{OH}\right)$, trace $(\mathrm{C})$ a reference spectrum of carbon monoxide and trace (D) the residual product spectrum obtained after subtraction of features due to chlorodifluoroacetic acid and carbon monoxide from the spectrum in trace $(A)$.

\section{Product distribution studies}

Fig. 2 shows typical product spectra recorded in the Cl-atom initiated oxidation of $\mathrm{CF}_{2} \mathrm{ClC}(\mathrm{O}) \mathrm{OCH}_{3}$. Trace (A) shows a product spectrum obtained after irradiation of a $\mathrm{Cl}_{2}$ / chlorofluoroester/air mixture and subtraction of residual MCDFA bands. It can be seen from a comparison of the spectrum with reference spectra of chlorodifluoroacetic acid (trace (B)) and carbon monoxide (trace (C)) that these two compounds are products formed in the $\mathrm{Cl}+$ MCDFA reaction. Trace (D) is the residual spectrum that is obtained after subtraction of known products from the spectrum in trace (A).

Concentration-time profiles of MCDFA and the identified products are shown in Fig. S3. $\dagger$ Plots of the concentration of the identified products as a function of reacted MCDFA (Fig. S4 in ESI $\dagger$ ) are linear supporting that they are primary products. From a minimum of 3 experiments averaged molar formation yields of $(34 \pm 5) \%$ and $(26 \pm 3) \%$ were obtained for chlorodifluoracetic acid and carbon monoxide, respectively.

In the reaction of $\mathrm{Cl}$ atoms with ethyl chlorodifluoroacetate, chlorodifluoracetic acid and carbon monoxide have been also identified as products. Fig. S5, $\uparrow$ trace (A), shows an IR spectra acquired after irradiation of a mixture of ECDFA and $\mathrm{Cl}_{2}$ in air where residual absorptions due to ECDFA have been subtracted. Fig. S5, $\uparrow$ trace (B), shows a reference spectra of chlorodifluoroacetic acid $\left(\mathrm{CF}_{2} \mathrm{ClC}(\mathrm{O}) \mathrm{OH}\right)$, trace (C) a reference spectra of carbon monoxide and trace (D) the residual spectrum that is obtained after subtraction of known products from the spectrum in trace (A).

Concentration-time profiles of ECDFA and the identified products chlorodifluoroacetic acid and carbon monoxide are shown in Fig. S6 in the ESI. $\uparrow$ The concentration-time contour of chlorodifluoroacetic acid and the linearity of the plot of its concentrations as a function of reacted ECDFA support that it is a primary product. Carbon monoxide shows the same behavior, however, as discussed later the $\mathrm{CO}$ is thought to result from the fast reaction of $\mathrm{Cl}$ atoms with $\mathrm{HCHO}$. Analysis of the slopes of the plots shown in Fig. $\mathrm{S} 7 \dagger$ give product yields of $(86 \pm 8) \%$ for chlorodifluoroacetic acid and $(34 \pm 6) \%$ for carbon monoxide in the reaction of $\mathrm{Cl}$ with ethyl chlorodifluoroacetate.

Table 2 lists the yields of the products formed in the reactions of MCDFA and ECDFA with $\mathrm{Cl}$ atoms. The errors quoted are a combination of the $2 \sigma$ statistical errors from the regression analysis plus a contribution to take into account the uncertainty in the spectral subtraction procedure.

In the atmosphere the oxidation of the saturated esters is mainly initiated by reaction with $\mathrm{OH}$ radicals and proceeds via $\mathrm{H}$-atom abstraction from the alkyl groups $\left(-\mathrm{CH}-,-\mathrm{CH}_{2}-,-\mathrm{CH}_{3}\right)$ in the ester forming alkyl radicals. The reactions of the haloesters studied with $\mathrm{Cl}$ atoms are less selective than the analogous $\mathrm{OH}$ reactions but the subsequent chemistry is similar. Thus, although reactions of $\mathrm{Cl}$-atoms with the esters are not so atmospherically important as the $\mathrm{OH}$ reactions, studies of their mechanisms are still necessary and are a convenient way to emulate $\mathrm{OH}$-radical initiated chemistry.

Under atmospheric conditions alkyl radicals react with oxygen to give peroxy radicals. The peroxy radicals formed can 
Table 2 Formation yields of the oxidation products identified in the $\mathrm{Cl}$-atom initiated oxidation of MCDFA and ECDFA at $298 \mathrm{~K}$ and atmospheric pressure of synthetic air

\begin{tabular}{lll}
\hline Chlorodifluoroacetate & Products identified & Yield (\%) \\
\hline $\mathrm{CF}_{2} \mathrm{ClC}(\mathrm{O}) \mathrm{OCH}_{3}$ & $\mathrm{CF}_{2} \mathrm{ClC}(\mathrm{O}) \mathrm{OH}$ & $34 \pm 5$ \\
(methyl chlorodifluoroacetate) & $\mathrm{CO}$ & $26 \pm 3$ \\
$\mathrm{CF}_{2} \mathrm{ClC}(\mathrm{O}) \mathrm{OCH}_{2} \mathrm{CH}_{3}$ & $\mathrm{CF}_{2} \mathrm{ClC}(\mathrm{O}) \mathrm{OH}$ & $86 \pm 8$ \\
(ethyl chlorodifluoroacetate) & $\mathrm{CO}$ & $34 \pm 6$
\end{tabular}

react with $\mathrm{NO}, \mathrm{NO}_{2}, \mathrm{HO}_{2}$, and other peroxy radicals forming, to a large extent, the corresponding alkoxy radicals. ${ }^{29}$ In the present $\mathrm{NO}_{x}$ free reaction systems the alkoxy radicals will be formed by reaction of the peroxy radicals with $\mathrm{RO}_{2} / \mathrm{HO}_{2}$ and those shown in Schemes 2 and 3 for MCDFA and ECDFA, respectively, are expected to be dominant.

Alkoxy radicals are known to react by three different pathways: (i) reaction with oxygen forming a carbonyl compound and $\mathrm{HO}_{2}$ radicals, (ii) decomposition via $\mathrm{C}-\mathrm{C}$ bond cleavage producing a stable product and a radical and, (iii) if possible, isomerization via a six-membered transition state producing polyfunctional compounds. In addition in the case of esters, the alkoxy radical, formed by $\mathrm{H}$-atom abstraction from the carbon attached to the non-carbonyl oxygen of the ester entity, can undergo what is known as an $\alpha$-ester rearrangement $t^{30}$ to form an acid and a radical. The products identified in the irradiation of MCDFA $/ \mathrm{Cl}_{2} /$ air and ECDFA $/ \mathrm{Cl}_{2} /$ air mixtures allow the elucidation of the fate of the alkoxy radicals.

a Atmospheric fate of $\mathrm{CF}_{2} \mathrm{ClC}(\mathrm{O}) \mathrm{OCH}_{2} \mathrm{O}^{\circ}$ radicals. Fig. 3 shows the possible fate of the $\mathrm{CF}_{2} \mathrm{ClC}(\mathrm{O}) \mathrm{OCH}_{2} \mathrm{O}^{\cdot}$ radicals

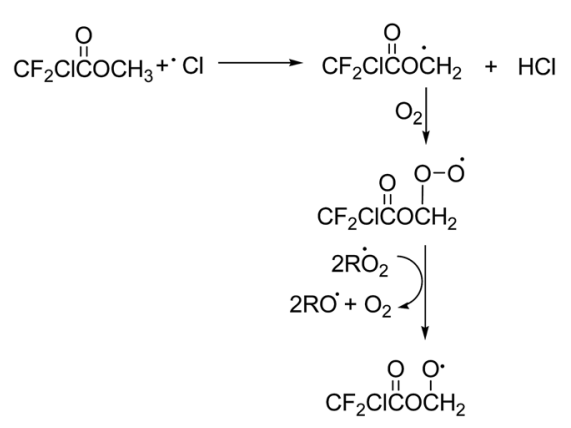

Scheme 2 Formation of alkoxy radicals in reaction of $\mathrm{Cl}+\mathrm{MCDFA}$.

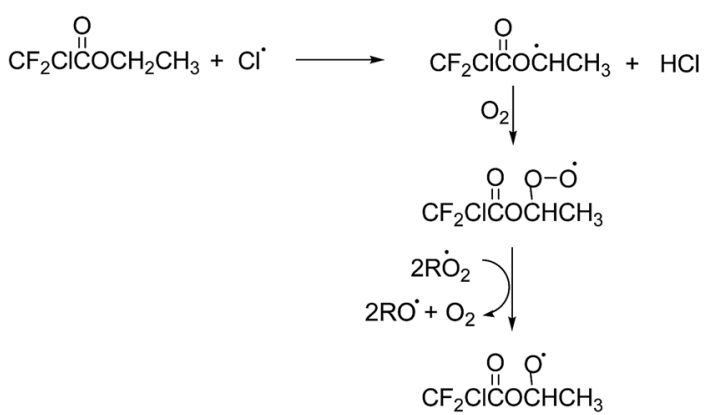

Scheme 3 Formation of alkoxy radicals in the reaction of $\mathrm{Cl}+$ ECDFA. formed in the reaction of MCDFA $+\mathrm{Cl}$. The observation of the formation of near equivalent amounts of chlorodifluoracetic acid and carbon monoxide around 30\% (see Table 2) supports that the $\mathrm{CF}_{2} \mathrm{ClC}(\mathrm{O}) \mathrm{OCH}_{2} \mathrm{O}^{\circ}$ radicals undergoes an $\alpha$-ester rearrangement (Fig. 3, channel A) forming the corresponding acid and $\mathrm{HCO}$ radicals which will react further with $\mathrm{O}_{2}$ to give CO and $\mathrm{HO}_{2}$ radicals. This is comparable to the acetic acid yield of around $30 \%$ obtained by Christensen et al. in their study on the reaction of $\mathrm{Cl}$ with methyl acetate in the absence of $\mathrm{NO}^{31}$ and a trifluoroacetic acid yield of $\sim 25 \%$ obtained by our group in a previous study on the reaction of $\mathrm{Cl}$ with methyl trifluoroacetate under similar conditions to this work. ${ }^{32}$

The possible $\mathrm{C}-\mathrm{O}$ bond cleavage decomposition channel of the $\mathrm{CF}_{2} \mathrm{ClC}(\mathrm{O}) \mathrm{OCH}_{2} \mathrm{O}^{\bullet}$ radical to form the $\mathrm{CF}_{2} \mathrm{ClC}(\mathrm{O}) \mathrm{O}^{\circ}$ radical and $\mathrm{HCHO}$ has been omitted in Fig. 3 since formation of formaldehyde was not observed in the reaction system. The $\mathrm{CF}_{2} \mathrm{ClC}(\mathrm{O}) \mathrm{O}^{\circ}$ radical can decompose to form $\mathrm{CO}_{2}$ and the $\mathrm{CF}_{2} \mathrm{Cl}^{\circ}$ radical which can react with $\mathrm{O}_{2}$ to form carbonyl fluoride $\left(\mathrm{CF}_{2} \mathrm{O}\right) \cdot{ }^{32}$ Carbonyl fluoride was observed in the system but its formation was clearly from secondary reactions. In addition, a previous study on the fate of the analogous alkoxy radical $\mathrm{CH}_{3} \mathrm{C}(\mathrm{O}) \mathrm{OCH}_{2} \mathrm{O}^{\circ}$ formed in the oxidation of methyl acetate has shown that the decomposition channel was also negligible. ${ }^{31}$

The reaction of $\mathrm{CF}_{2} \mathrm{ClC}(\mathrm{O}) \mathrm{OCH}_{2} \mathrm{O}$ radicals with $\mathrm{O}_{2}$ will lead to the formation of the mixed acid anhydride $\mathrm{CF}_{2} \mathrm{ClC}(\mathrm{O}) \mathrm{OC}(\mathrm{O}) \mathrm{H}$ (Fig. 3, channel B). Since a reference spectrum for $\mathrm{CF}_{2} \mathrm{ClC}(\mathrm{O})$ $\mathrm{OC}(\mathrm{O}) \mathrm{H}$ is not commercially available, it was not possible to directly assign absorptions bands in the product spectrum to this compound. Preparative methods are known for mixed anhydrides such as $\mathrm{CF}_{2} \mathrm{ClC}(\mathrm{O}) \mathrm{OC}(\mathrm{O}) \mathrm{H}^{33}$ unfortunately infrared spectra for the compounds have not yet been reported and it was beyond the scope of the present work to synthesize $\mathrm{CF}_{2}-$ $\mathrm{ClC}(\mathrm{O}) \mathrm{OC}(\mathrm{O}) \mathrm{H}$. However, anhydrides are known important products in the $\mathrm{Cl}$-atom mediated oxidation of alkyl acetates

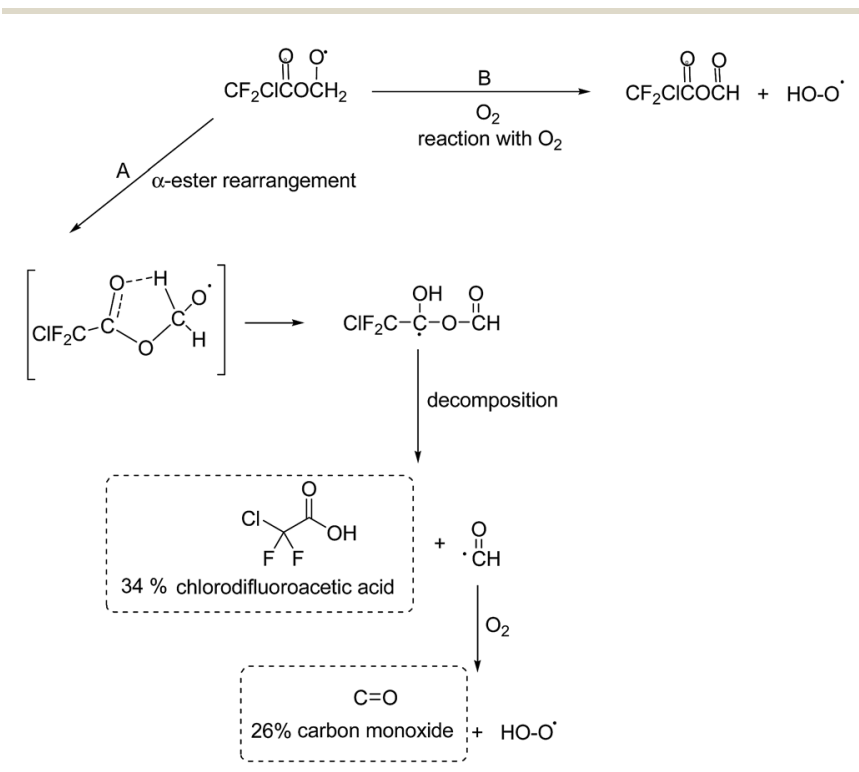

Fig. 3 Atmospheric fate of the alkoxy radicals formed after $\mathrm{H}$-atom abstraction by $\mathrm{Cl}$ from the $-\mathrm{CH}_{3}$ group in MCDFA. The dashed boxes indicate the identified and quantified products formed. 
and alkyl haloacetates. ${ }^{30,31}$ The residual product spectrum bares many similarities with that obtained in the study of $\mathrm{Cl}$ atoms with $\mathrm{CF}_{3} \mathrm{C}(\mathrm{O}) \mathrm{OCH}_{3}$ where the main absorptions bands were assigned to formic trifluoroacetic anhydride $\mathrm{CF}_{3} \mathrm{C}(\mathrm{O}) \mathrm{OCHO}^{32}$

The unique structural feature of an anhydride is the presence of two carbonyl groups linked to each other via an oxygen atom. This structure gives rise to two carbonyl absorptions in the infrared arising from symmetrical and asymmetrical stretching of the carbonyl groups. The residual product spectrum from $\mathrm{Cl}+$ MCDFA contains two carbonyl absorptions at 1831 and $1805 \mathrm{~cm}^{-1}$ separated by $26 \mathrm{~cm}^{-1}$ whereby the absorption at $1805 \mathrm{~cm}^{-1}$ is stronger than that at $1831 \mathrm{~cm}^{-1}$. The small carbonyl band splitting is expected for anhydrides of structure $\mathrm{RC}(\mathrm{O}) \mathrm{OCHO} .{ }^{34}$ In the fingerprint region of the product spectrum band maxima occur at $\sim 1279, \sim 1193, \sim 1115, \sim 999$, $\sim 966 \mathrm{~cm}^{-1}$ whereby those at 1115 and $966 \mathrm{~cm}^{-1}$ are the strongest and equally intense. Interpretation of anhydride spectra in the fingerprint region is complicated because of a large number of $\mathrm{C}-\mathrm{O}$ and $\mathrm{C}-\mathrm{C}$ stretchings and various bending modes, many of which are strongly mixed. The strong band at $1115 \mathrm{~cm}^{-1}$ is an indication for the presence of an anhydride and is generally associated with $\mathrm{C}-\mathrm{O}$ and $\mathrm{C}-\mathrm{C}$ vibrations. However, although many anhydrides have strong bands in this region it is not a unique marker for the presence of an anhydride since many other compounds absorb in this region. ${ }^{35,36}$ The bands at 1279 and $1193 \mathrm{~cm}^{-1}$ are consistent with vibrations from $\mathrm{C}-\mathrm{F}$ and $\mathrm{C}-\mathrm{Cl}$ in the $\mathrm{ClF}_{2} \mathrm{C}$ - group: similar bands occur in the infrared spectra of formic trifluoroacetic anhydride and trifluoroacetic anhydride. ${ }^{35-37}$ The absorption bands at $\sim 999$ and $\sim 960 \mathrm{~cm}^{-1}$ are most probably also from $\mathrm{C}-\mathrm{F}$ and $\mathrm{C}-\mathrm{Cl}$ vibrations, halogenated compounds such as 1,2-dichlorotetrafluoroethane show fairly strong bands in this region.

An infrared spectrum has been simulated for $\mathrm{CF}_{2} \mathrm{ClC}(\mathrm{O})$ $\mathrm{OC}(\mathrm{O}) \mathrm{H}$ using the using Gaussian 03 ab initio quantum chemistry package. ${ }^{38}$ The spectrum was calculated using the B3LYP/6 $31+\mathrm{G}$ level of theory. ${ }^{39-41}$ The simulated infrared spectrum is compared in Fig. $\mathrm{S} 8, \uparrow$ panel $\mathrm{B}$, with the residual product spectrum (panel A) from the Cl + MCDFA reaction. Although the computed spectrum captures the main spectral features of the experimental absorption bands reasonably well, there are large discrepancies in the absorption frequencies especially for the carbonyl bands. The computed spectrum, however, does lend additional support to the other spectral experimental evidence that the residual product spectrum is very probably mainly due to formation of $\mathrm{CF}_{2} \mathrm{ClC}(\mathrm{O}) \mathrm{OC}(\mathrm{O}) \mathrm{H}$ from reaction of $\mathrm{CF}_{2} \mathrm{ClC}(\mathrm{O})$ $\mathrm{OCH}_{2} \mathrm{O}^{\cdot}$ radicals with $\mathrm{O}_{2}$. Secondary reactions of $\mathrm{CF}_{2} \mathrm{ClC}(\mathrm{O})$ $\mathrm{OC}(\mathrm{O}) \mathrm{H}$ with $\mathrm{Cl}$ are the most probable source of the small amounts of $\mathrm{F}_{2} \mathrm{CO}$ observed in the reaction system.

b Atmospheric fate of $\mathrm{CF}_{2} \mathrm{ClC}(\mathrm{O}) \mathrm{OCHO} \cdot \mathrm{CH}_{3}$ radicals. Mishra et $a l .{ }^{27}$ have reported that $\mathrm{H}$-atom abstraction from the $\mathrm{CH}_{3}$ - group in $\mathrm{CF}_{2} \mathrm{ClC}(\mathrm{O}) \mathrm{OCH}_{2} \mathrm{CH}_{3}$ at $298 \mathrm{~K}$ to give the $\mathrm{CF}_{2}$ $\mathrm{ClC}(\mathrm{O}) \mathrm{OCH}_{2} \mathrm{CH}_{2}{ }^{\cdot}$ radical is very slow $\left(k=3.88 \times 10^{-14} \mathrm{~cm}^{3}\right.$ per molecule per $\mathrm{s}$ ) compared to $\mathrm{H}$-atom abstraction from the $-\mathrm{CH}_{2}$ - group to give the $\mathrm{CF}_{2} \mathrm{ClC}(\mathrm{O}) \mathrm{OCH} \cdot \mathrm{CH}_{3}$ radical $(k=1.82 \times$ $10^{-12} \mathrm{~cm}^{3}$ per molecule per $\mathrm{s}$ ). The authors reported that the barrier heights for hydrogen abstraction from the $-\mathrm{CH}_{2}-$ group by $\mathrm{Cl}$ at both the MPWB1K and G2(MP2) levels of theory are lower than the corresponding values for the $-\mathrm{CH}_{3}$ site indicating that the formation of $\mathrm{CF}_{2} \mathrm{ClC}(\mathrm{O}) \mathrm{OCHO} \cdot \mathrm{CH}_{3}$ radicals is the main fate for the reaction of $\mathrm{Cl}$ with ECDFA (see Scheme 3). However, they concluded that some $\mathrm{H}$-abstraction from the $-\mathrm{CH}_{3}$ group in ECDFA could occur and could not be completely excluded. Orlando and Tyndall ${ }^{42}$ have studied the reaction of $\mathrm{Cl}$ with ethyl acetate and found that $\mathrm{Cl}$ atom attack at the $-\mathrm{CH}_{2}-$ group dominates for this non-halogenated ester.

The experimental evidence in this work, i.e. the high formation yield of chlorodifluoroacetic acid, also supports that in the reaction of $\mathrm{Cl}$ with ECDFA attack of the $\mathrm{Cl}$ atom at the $-\mathrm{CH}_{2}-$ group dominates. The $\mathrm{CF}_{2} \mathrm{ClC}(\mathrm{O}) \mathrm{OCH} \cdot \mathrm{CH}_{3}$ radical thus formed will add $\mathrm{O}_{2}$ to form a peroxy radical further reactions of which with $\mathrm{RO}_{2} / \mathrm{HO}_{2}$ will yield to a large extent the alkoxy radical $\mathrm{CF}_{2} \mathrm{ClC}(\mathrm{O}) \mathrm{OCHO} \cdot \mathrm{CH}_{3}$. A simplified mechanism showing the further possible reaction pathways of the $\mathrm{CF}_{2}$ $\mathrm{ClC}(\mathrm{O}) \mathrm{OCHO} \cdot \mathrm{CH}_{3}$ radical is presented in Fig. 5 .

The observation of a high chlorodifluoroacetic acid yield ( $\sim 85 \%$ ) supports that the $\alpha$-ester rearrangement (Fig. 4 , channel A) is the main reaction channel for the $\mathrm{CF}_{2} \mathrm{ClC}(\mathrm{O}) \mathrm{OCHO} \cdot \mathrm{CH}_{3}$ radical, assuming that no other source of the acid exists. Blanco et al. ${ }^{32}$ in their study on the $\mathrm{Cl}$-atom oxidation of fluoroacetates report a value of $78 \pm 5 \%$ for the formation of trifluoroacetic acid in the reaction of $\mathrm{Cl}$ with ethyl trifluoroacetate. Orlando and Tyndall ${ }^{42}$ have reported a yield of $53 \%$ for the formation of acetic acid in the reaction of $\mathrm{Cl}$ with ethyl acetate and concluded from their system analysis that other routes to the formation of the acid were very minor. In addition, Tuazón et $a .^{30}$ and Picquet-Varrault et al. ${ }^{43}$ have reported yields of $96 \%$ and $75 \%$ for the formation of acetic acid in the reaction of $\mathrm{OH}$ radicals with $\mathrm{CH}_{3} \mathrm{C}(\mathrm{O}) \mathrm{OCH}_{2} \mathrm{CH}_{3}$, respectively. All of these studies are consistent with the main reaction pathway being abstraction of an $\mathrm{H}$-atom from the $-\mathrm{CH}_{2}$ - group with subsequent chemistry via an $\alpha$-ester rearrangement leading to the corresponding acid compound.

The co-product of $\mathrm{CF}_{2} \mathrm{ClC}(\mathrm{O}) \mathrm{OH}$, the $\mathrm{CH}_{3} \mathrm{C}(\mathrm{O})$ radical, will add $\mathrm{O}_{2}$ to form the $\mathrm{CH}_{3} \mathrm{C}(\mathrm{O}) \mathrm{OO}$ peroxy radical. This radical can react with $\mathrm{HO}_{2}$ to form peroxy acetic acid $\left(\mathrm{CH}_{3} \mathrm{C}(\mathrm{O}) \mathrm{OOH}\right)$, or react with other peroxy radicals to form $\mathrm{CO}_{2}$ and $\mathrm{CH}_{3}$ radicals. No evidence for formation of peroxy acetic acid was been observed in the residual product spectrum, however, an $\mathrm{OH}$ absorption was observed at $\sim 3585 \mathrm{~cm}^{-1}$ suggesting formation of a product containing either an $\mathrm{OH}$ or $\mathrm{OOH}$ group. Although $\mathrm{CO}_{2}$ cannot be quantitatively determined in the system because of high background levels, there where indications that its concentration increased during the course of the reaction. The $\mathrm{CH}_{3}$ radical will be oxidized to formaldehyde (HCHO) the further reaction of which will give CO. Formaldehyde could not be detected in the reaction system, which is not surprising given the high reactivity of $\mathrm{HCHO}$ with $\mathrm{Cl}$. Orlando and Tyndall ${ }^{42}$ in their study on the reaction of $\mathrm{Cl}$ with ethyl acetate could only detect traces of HCHO. Interestingly, the acid to $\mathrm{CO}$ ratio in this study on $\mathrm{Cl}$ with $\mathrm{CF}_{2} \mathrm{ClC}(\mathrm{O}) \mathrm{OCH}_{2} \mathrm{CH}_{3}$ and in the studies on $\mathrm{Cl}$ with $\mathrm{CF}_{3} \mathrm{C}(\mathrm{O}) \mathrm{OCH}_{2} \mathrm{CH}_{3}{ }^{32}$ and $\mathrm{Cl}$ with $\mathrm{CH}_{3} \mathrm{C}(\mathrm{O}) \mathrm{OCH}_{2} \mathrm{CH}_{3}{ }^{42}$ are all $\sim 0.4$ indicating other fates for the $\mathrm{CH}_{3} \mathrm{C}(\mathrm{O})$ radical rather than oxidation through $\mathrm{HCHO}$ to $\mathrm{CO}$. It was not possible to 


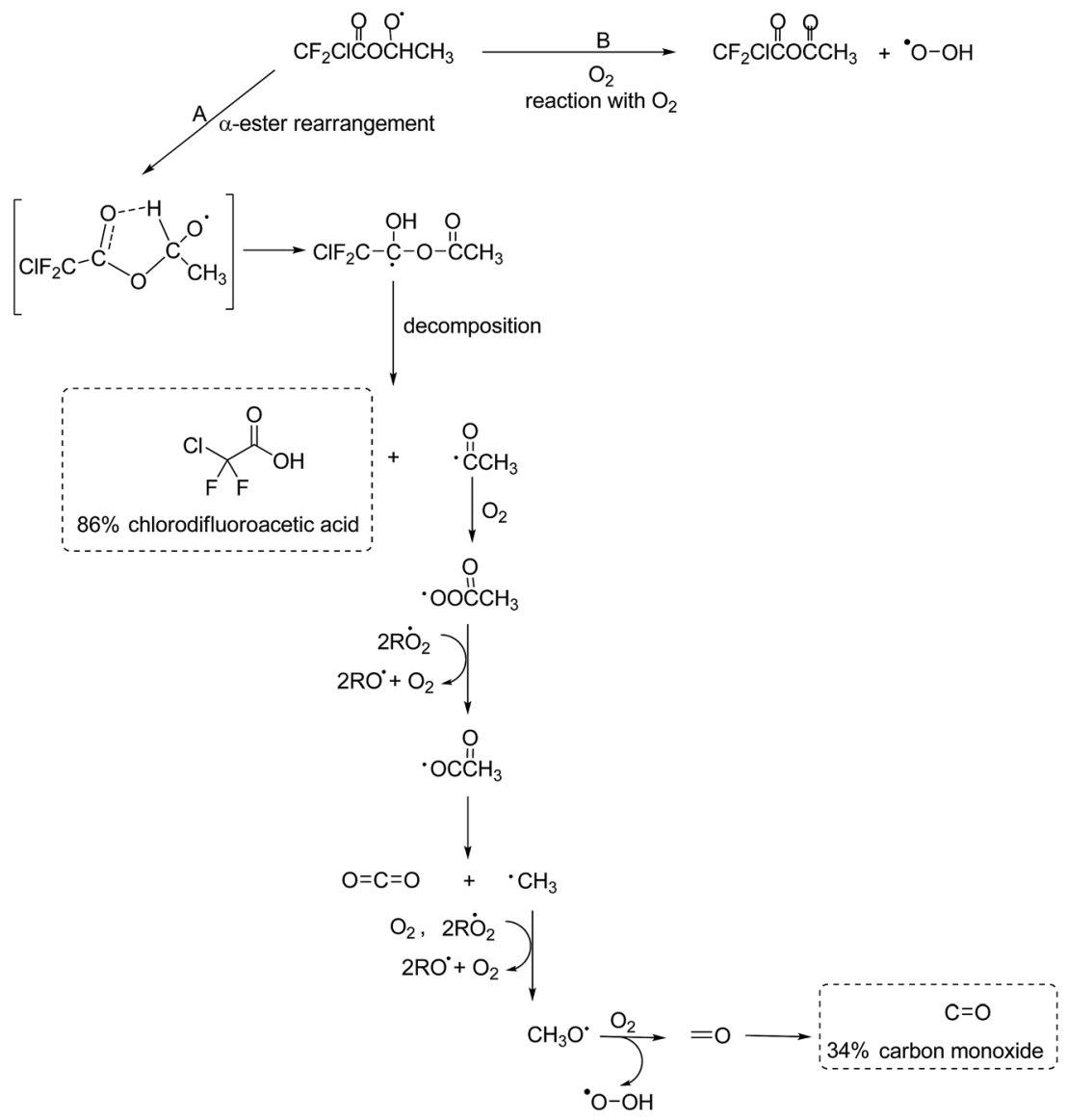

Fig. 4 Atmospheric fate of the alkoxy radicals formed after $\mathrm{H}$-atom abstraction by $\mathrm{Cl}$ from the $-\mathrm{CH}_{2}-$ group in ECDFA. The dashed boxes indicate the identified and quantified products formed.

elucidate the other reaction pathways from the present FTIR data.

The $\mathrm{CF}_{2} \mathrm{ClC}(\mathrm{O}) \mathrm{OCHO} \cdot \mathrm{CH}_{3}$ alkoxy radical could potentially decompose via a $\mathrm{C}-\mathrm{O}-\mathrm{C}$ bond cleavage forming $\mathrm{CF}_{2} \mathrm{ClC}(\mathrm{O}) \mathrm{O}^{\circ}$ radicals and acetaldehyde. The $\mathrm{CF}_{2} \mathrm{ClC}(\mathrm{O}) \mathrm{O}^{\circ}$ radicals would be expected to decompose to form $\mathrm{CO}_{2}$ and ${ }^{\circ} \mathrm{CF}_{2} \mathrm{Cl}$ radicals and the subsequent reactions of which would be expected to produce $\mathrm{CF}_{2} \mathrm{O}$. Neither the formation of $\mathrm{CF}_{2} \mathrm{O}$ nor formation of the decomposition co-product acetaldehyde was observed in the product spectra suggesting that the contribution from this channel was negligible. The absence of $\mathrm{CF}_{2} \mathrm{O}$ also shows that no other reaction product was oxidized through to $\mathrm{CF}_{2} \mathrm{O}$ in the reaction system.

The absorption bands in the residual product spectrum from the reaction of $\mathrm{Cl}$ with ECDFA are not as distinct as in the residual product spectrum for $\mathrm{Cl}$ with MCDFA with more overlapping of bands which suggests more than one compound is present. Indeed, a comparison of the residual product spectrum from $\mathrm{Cl}$ with MCDFA, which has been identified as belonging mainly to the anhydride $\mathrm{ClCF}_{2} \mathrm{C}(\mathrm{O}) \mathrm{OCHO}$, with that of $\mathrm{Cl}$ with ECDFA shows that $\mathrm{ClCF}_{2} \mathrm{C}(\mathrm{O}) \mathrm{OCHO}$ is formed in the reaction of $\mathrm{Cl}$ with ECDFA. After subtraction of the absorptions due to $\mathrm{ClCF}_{2} \mathrm{C}(\mathrm{O}) \mathrm{OCHO}$, the following absorptions remain at $\sim 1864$, $\sim 1819, \sim 1302, \sim 1169, \sim 1125, \sim 1093$ (shoulder) and $\sim 978$ $\mathrm{cm}^{-1}$. The two carbonyl absorptions at 1864 and $819 \mathrm{~cm}^{-1}$ are separated by $45 \mathrm{~cm}^{-1}$, whereby $1819 \mathrm{~cm}^{-1}$ is the stronger of the two. As discussed for the assignment of $\mathrm{CClF}_{2} \mathrm{C}(\mathrm{O}) \mathrm{OC}(\mathrm{O}) \mathrm{H}$ as a product in the reaction of $\mathrm{Cl}$ with MCDFA, bands at $\sim 1302$, $\sim 1169$ and $\sim 978 \mathrm{~cm}^{-1}$ are consistent with $\mathrm{C}-\mathrm{F}$ and $\mathrm{C}-\mathrm{Cl}$ vibrations from the $\mathrm{ClF}_{2} \mathrm{C}$ - group and a strong absorption at $\sim 1125 \mathrm{~cm}^{-1}$ would fit with a $\mathrm{C}-\mathrm{O}-\mathrm{C}$ type vibration. These observed absorptions are consistent with the formation of the anhydride $\mathrm{CF}_{2} \mathrm{ClC}(\mathrm{O}) \mathrm{OC}(\mathrm{O}) \mathrm{CH}_{3}$ from the reaction of $\mathrm{CF}_{2} \mathrm{ClC}(\mathrm{O})$ OCHO $\cdot \mathrm{CH}_{3}$ radical with $\mathrm{O}_{2}$ (Fig. 4, channel B). This anhydride is not commercially available for quantification purposes, however, the high yield of $\mathrm{CF}_{2} \mathrm{ClC}(\mathrm{O}) \mathrm{OH}$ and evidence for the formation of $\mathrm{CF}_{2} \mathrm{ClC}(\mathrm{O}) \mathrm{OC}(\mathrm{O}) \mathrm{H}$ suggest that its yield is probably $<10 \%$.

\section{Atmospheric implications}

Methyl chlorodifluoracetate and ethyl chlorodifluoroacetate are removed from the troposphere mainly by their rapid reactions with $\mathrm{OH}$ radicals ${ }^{16}$ which results in atmospheric lifetimes of the order of 10-50 days. However, in some marine and continental regions close to industrial emissions, peak values of $1 \times 10^{5}$ atoms per $\mathrm{cm}^{3}$ for $\mathrm{Cl}$ atoms concentrations have been observed..$^{3-11}$ Under such circumstances the reaction of $\mathrm{Cl}$ with the chlorofluoroacetates can be a significant if not dominant 
loss process for the compounds. Photolysis is not an important atmospheric loss process for these chlorofluorinated compounds since they do not absorb radiation at actinic wavelengths. ${ }^{16}$

As reported for other haloesters ${ }^{\mathbf{4 4 , 4 5}}$ we expect relatively low values of the Henry laws constants at $298 \mathrm{~K}$ for both compounds, indicating that wet deposition of these chlorofluoro acetates will not be significant compared to the $\mathrm{OH}$-radical or Cl-atom initiated degradation. The volatility of these compounds will render dry deposition an unlikely removal mechanism.

The temperature dependences of the Cl-rate coefficients reported in this work were used to calculate the rate of loss of the chlorofluoroacetates studied by their tropospheric reaction with $\mathrm{Cl}$ atoms. At a given temperature $(T)$ corresponding to a given altitude in the troposphere, the rate of loss of the chlorofluoracetates is defined as the product between the $\mathrm{Cl}$ rate coefficient $(T)$ and the $[\mathrm{Cl}]$ at this altitude.

Using a $24 \mathrm{~h}$ daytime average global tropospheric $\mathrm{Cl}$ atom concentration of $[\mathrm{Cl}]=1 \times 10^{4}$ atoms per $\mathrm{cm}^{3},{ }^{46}$ the Arrhenius parameters reported in this work and considering a lapse rate in the troposphere of $-6.5 \mathrm{~K} \mathrm{~km}^{-1},{ }^{47}$ we have calculated the temperature profile between 0 and $10 \mathrm{~km}$. Table $\mathrm{S} 1 \dagger$ shows the $\mathrm{Cl}$ removal rates for the chlorofluoroacetates studied as a function of altitude in the troposphere considering temperature of $298.15 \mathrm{~K}$ at $0 \mathrm{~km}$. The results showed in Table S1 $\uparrow$ are plotted in the Fig. 5 .

The loss rates (in s ${ }^{-1}$ ) of the haloacetates studied at sea level $(0 \mathrm{~km})$ are $9.93 \times 10^{-10}$ and $1.55 \times 10^{-8}$ and near to the tropopause $(\sim 10 \mathrm{~km})$ around $2.78 \times 10^{-10}$ and $5.51 \times 10^{-9}$ for methyl chlorodifluoroacetate and ethylchlorodifluoroacetate, respectively.

The positive temperature dependence of the reactions of $\mathrm{Cl}$ atoms with both MCDFA and ECDFA is consistent with the dominance of a hydrogen atom abstraction mechanism.

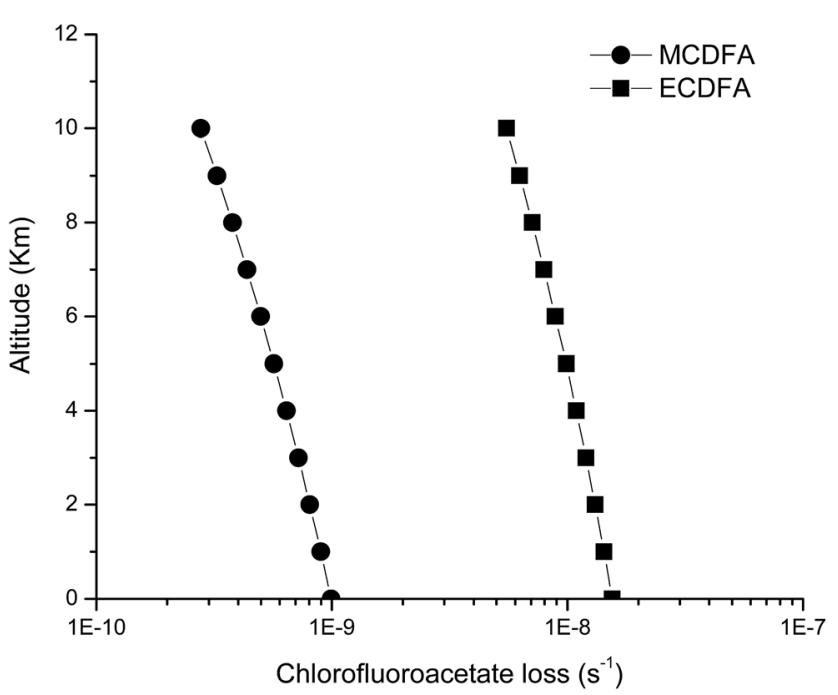

Fig. 5 Loss rates for methyl chlorodifluoracetate $(0)$ and ethyl chlorodifluoracetate ( $\mathbf{\square})$ through reaction with $\mathrm{Cl}$ atoms as a function of altitude $(\mathrm{km})$ of the atmosphere.
The product investigations presented in this work have shown that the major product of the Cl-atom initiated oxidation of methyl chlorodifluoroacetate under $\mathrm{NO}_{x}$-free conditions will be formic dichlorofluoroacetic anhydride $\left(\mathrm{CF}_{2} \mathrm{ClC}(\mathrm{O}) \mathrm{OC}(\mathrm{O}) \mathrm{H}\right)$. We expect that chlorofluoro anhydride will be further oxidized fairly rapidly by reaction with $\mathrm{OH}$ radicals and may also photolyze since the compound contains the $-\mathrm{C}(\mathrm{O}) \mathrm{H}$ chromophore. The other product observed in the reaction of $\mathrm{Cl}$ with MCDFA was chlorodifluoracetic acid ( 30\%). Both, anhydrides and acids are highly soluble compounds and may be rapidly incorporated into cloud droplets (where hydration of the anhydrides leads to acids) and rain out, contributing to the precipitation acidity.

For the reaction of $\mathrm{Cl}$ with ETFA the main product observed was chlorodifluoroacetic acid $(\sim 88 \%)$. Haloacetic acids are ubiquitous environmental pollutants and their presence in the environment is due both to natural processes and to human activities. They partition into water because of their large Henry's law constants. ${ }^{\mathbf{4 8} 49}$ They could be accumulated to relatively high concentrations in aqueous reservoirs and would likely accumulate to toxic levels. Furthermore, haloacetic acids have been detected in many places such as soil, conifer needles and lichens, snow and ice in Antarctica, fog and rainwater, sea water, lake water, wastewater and drinking water. ${ }^{50,51}$ Haloacetic acids, as chlorodifluoracetic acid are generally phytotoxic and toxic to green algae, ${ }^{52}$ while some haloacetic acids, e.g., dichloroacetic acid and trichloracetic acid, have hepatocarcinogenic potential. ${ }^{53}$

In this sense, studies of the tropospheric degradation of chlorofluoroacetates are important and necessary, since these compounds break down relatively rapidly to several products including persistent substances such as chlorodifluoroacetic acid. Concentrations of CDFA with a maximum of $0.0002 \mathrm{ng} \mathrm{L}^{-1}$ were reported in water samples taken in Canada. ${ }^{\mathbf{4 8}}$ However, a continuing monitoring of the environmental concentrations of CDFA is recommended to confirm trends in surface and rainwater.

In addition, further studies on the product distributions from the $\mathrm{OH}$-radical and $\mathrm{Cl}$-atom initiated oxidation of haloesters need to be performed over the range of temperatures and $\mathrm{NO}_{x}$ levels typically prevailing in the troposphere in order to gain a better quantitative understanding of their contribution to photooxidant formation and precipitation acidity.

\section{Acknowledgements}

The authors wish to acknowledge Deutsche Forschungsgemeinschaft (DFG), DAAD-MINCyT, FONCyT and CONICET for financial support of this research. M. B. Blanco wishes to acknowledge to the Alexander von Humboldt Foundation for support through a postdoctoral fellowship.

\section{References}

$1 \mathrm{~W}$. T. Tsai, Environmental risk assessment of hydrofluoroethers (HFEs), J. Hazard. Mater., 2005, 119, 6978. 
2 A. Sekiya and S. Misaki, J. Fluorine Chem., 2000, 101, 215-221. 3 C. W. Spicer, E. G. Chapman, B. J. Finlayson-Pitts, R. A. Plastridge, J. M. Hubbe, J. D. Fast and C. M. Berkowitz, Nature, 1998, 394, 353-356.

4 W. C. Keene, A. A. P. Pszenny, D. J. Jacob, R. A. Duce, J. N. Galloway, J. J. Schultz Tokos, H. Sievering and J. F. Boatman, Global Biogeochemistry Cycles, 1990, vol. 4, pp. 407-430.

5 B. J. Finlayson-Pitts, Res. Chem. Intermed., 1993, 19, 235-249.

6 C. George, W. Behnke and C. Zetzsch, ChemPhysChem, 2010, 11, 3059-3062.

7 J. A. Thornton, J. P. Kercher, T. P. Riedel, N. L. Wagner, J. Cozic, J. S. Holloway, W. P. Dubé, G. M. Wolfe, P. K. Quinn, A. M. Middlebrook, B. Alexander and S. S. Brown, Nature, 2010, 464, 271-274.

8 H. D. Osthoff, J. M. Roberts, A. R. Ravishankara, E. J. Williams, B. M. Lerner, R. Sommariva, T. S. Bates, D. Coffman, P. K. Quinn, J. E. Dibb, H. Stark, J. B. Burkholder, R. K. Talukdar, J. Meagher, F. C. Fehsenfeld and S. S. Brown, Nature Geoscience, 2008, 1, 324-328.

9 G. J. Phillips, M. J. Tang, J. Thieser, B. Brickwedde, G. Schuster, B. Bohn, J. Lelieveld and J. N. Crowley, Geophys. Res. Lett., 2012, 39, L10811, DOI: 10.1029/ $2012 \mathrm{gl051912.}$

10 C. J. Young, R. A. Washenfelder, J. M. Roberts, L. H. Mielke, H. D. Osthoff, C. Tsai, O. Pikelnaya, J. Stutz, P. R. Veres, A. K. Cochran, T. C. VandenBoer, J. Flynn, N. Grossberg, C. L. Haman, B. Lefer, H. Stark, M. Graus, J. de Gouw, J. B. Gilman, W. C. Kuster and S. S. Brown, Environ. Sci. Technol., 2012, 46, 10965-10973.

11 E. Galán, I. González and B. Fabbri, Estimation of fluorine and chlorine emissions from Spanish structural ceramic industries, Atmos. Environ., 2002, 36, 5289-5298.

12 G. James, M. Neil Jr and D. J. Burton, J. Fluorine Chem., 1991, $55,225-227$.

13 D. Desbouis, R. Hardré and M. Réglier, Ethyl chlorodifluoroacetate. e-EROS Encyclopedia of Reagents for Organic Synthesis, 2009, DOI: 10.1002/047084289X.rn00987.

14 N. Oyaro, S. R. Sellevag and C. J. Nielsen, Environ. Sci. Technol., 2004, 38, 5567-5576.

15 M. P. Sulback Andersen, O. J. Nielsen, T. J. Wallington, M. D. Hurley and G. W. DeMoore, J. Phys. Chem. A, 2005, 109, 3926-3934.

16 M. B. Blanco and M. A. Teruel, Chem. Phys. Lett., 2007, 441, 1-6.

17 J. W. Martin, J. Franklin, M. L. Hanson, K. R. Solomon, S. A. Mabury, D. A. Ellis, B. F. Scott and D. C. G. Muir, Environ. Sci. Technol., 2000, 34, 274-281.

18 I. Barnes and K. H. Becker, J. Atmos. Chem., 1994, 18, 267289.

19 R. Atkinson, D. L. Baulch, R. A. Cox, J. N. Crowley, R. F. Jr Hampson, J. A. Kerr, M. J. Rossi and J. Troe, IUPAC Subcommittee on Gas Kinetic Data Evaluation for Atmospheric Chemistry Web Version, Dec 2001.
20 A. Aranda, Y. Díaz de Mera, I. Bravo, D. Rodríguez, A. Rodríguez and E. Martínez, Environ. Sci. Technol., 2006, 40, 5971-5976.

21 Y. Díaz de Mera, A. Aranda, I. Bravo, E. Moreno, E. Martínez and A. Rodríguez, Chem. Phys. Lett., 2009, 479, 20-24.

22 A. Rodríguez, D. Rodríguez, A. Moraleda, I. Bravo, E. Moreno and A. Notario, Atmos. Environ., 2014, 96, 145-153.

23 M. B. Blanco, I. Barnes, P. Wiesen and M. A. Teruel, Chem. Phys. Lett., 2015, 638, 15-20.

24 B. K. Mishra, A. K. Chakrabartty and R. C. Deka, J. Mol. Model., 2013, 19, 3263-3270.

25 E. P. Z. Wigner, Phys. Chem., 1932, B19, 203-216.

26 C. Eckart, Phys. Rev., 1930, 35, 1303-1309.

27 B. K. Mishra, A. K. Chakrabartty and R. C. Deka, Struct. Chem., 2014, 25, 463-470.

28 J.-H. Xing, K. Takahashi, M. D. Hurley and T. J. Wallington, Chem. Phys. Lett., 2009, 474, 268-272.

29 J. J. Orlando and G. S. Tyndall, Chem. Soc. Rev., 2012, 41, 6294-6317.

30 E. C. Tuazón, S. M. Aschmann, R. Atkinson and W. P. L. Carter, J. Phys. Chem., 1998, 102, 2316-2321.

31 L. K. Christensen, J. C. Ball and T. J. Wallington, J. Phys. Chem. A, 2000, 104, 345-351.

32 M. B. Blanco, I. Bejan, I. Barnes, P. Wiesen and M. A. Teruel, Atmospheric photooxidation of fluoroacetates as a source of fluorocarboxylic acids, Environ. Sci. Technol., 2010, 44, 23542359.

33 J. Codnia and M. L. Azcárate, Photochem. Photobiol., 2006, 82, 755-762.

34 S. Montiel-Smith, S. Meza-Reyes, O. Viňas-Bravo, M. A. Fernández-Herrera, R. Martinez-Pascual, J. SandovalRamírez, A. Fuente, M. Reyes and J. A. Ruiz, ARKIVOC, 2005, vi, 127-135.

35 G. Wu, S. Shlykov, C. Van Alsenoy, H. J. Geise, E. Sluyts and B. J. Van der Veken, J. Phys. Chem., 1996, 100, 11620-11629. 36 L. J. Bellamy, The Infrared Spectra of Complex Molecules, Chapman and Hall, London, II, 2nd edn, 1980.

37 R. L. Redington and K. C. Lin, Spectrochim. Acta, Part A, 1971, 27, 2445-2460.

38 M. J. Frisch, G. W. Trucks, H. B. Schlegel, G. E. Scuseria, M. A. Robb, J. R. Cheeseman, J. A. Montgomery, T. Jr Vreven, N. Kudin, J. C. Burant, J. M. Millam, S. S. Iyengar, J. Tomasi V. Barone, B. Mennucci, M. Cossi, G. Scalmani, N. Rega, G. A. Petersson, H. Nakatsuji, M. Hada, M. Ehara, K. Toyota, R. Fukuda, J. Hasegawa, M. Ishida, T. Nakajima, Y. Honda, O. Kitao, H. Nakai, M. Klene, X. Li, J. E. Knox, H. P. Hratchian, J. B. Cross, C. Adamo, J. Jaramillo, R. Gomperts, R. E. Stratmann, O. Yazyev, A. J. Austin, R. Cammi, C. Pomelli; J. W. Ochterski, P. Y. Ayala, K. Morokuma, G. A. Voth, P. Salvador, J. J. Dannenberg, V. G. Zakrzewski, S. Dapprich, A. D. Daniels, M. C. Strain, O. Farkas, D. K. Malick, A. D. Rabuck, K. Raghavachari, J. B. Foresman, J. V. Ortiz, Q. Cui, A. G. Baboul, S. Clifford, J. Cioslowski, B. B. Stefanov, G. Liu, A. Liashenko, P. Piskorz, I. Komaromi, R. L. Martin, D. J. Fox, T. Keith, M. A. Al-Laham, C. Y. Peng, A. Nanayakkara, M. Challacombe, P. M. W. Gill, B. Johnson, W. Chen, 
M. W. Wong, C. Gonzalez and J. A. Pople, Gaussian Inc., Wallingford, CT, 2004.

39 A. D. Becke, J. Chem. Phys., 1993, 98, 5648-5652.

40 C. Lee, W. Yang and R. G. Parr, Phys. Rev. B: Condens. Matter Mater. Phys., 1988, 37, 785-789.

41 B. Miehlich, A. Savin, H. Stoll and H. Preuss, Chem. Phys. Lett., 1989, 157, 200-206.

42 J. J. Orlando and G. S. Tyndall, Int. J. Chem. Kinet., 2010, 32, 397-413.

43 B. Picquet-Varrault, J. F. Doussin, R. Durand-Jolibois and P. Carlier, Phys. Chem. Chem. Phys., 2001, 3, 2595-2606.

44 S. Kutsuna, L. Chen, K. Ohno, K. Tokuhashi and A. Sekiya, Atmos. Environ., 2004, 38, 725-738.

45 S. Kutsuna, L. Chen, T. Abe, J. Mizukado, T. Uchimaru, K. Tokuhashi and A. Sekiya, Atmos. Environ., 2005, 39, 5884-5892.
46 O. W. Wingenter, M. K. Kubo, N. J. Blake, T. W. Smith, D. R. Blake and F. S. Rowland, J. Geophys. Res., 1996, 101, 4331-4340.

47 M. Beychok, 2013, http:/www.eoearth.org/view/article/ 170859.

48 J. W. Martin, J. Franklin, M. L. Hanson, K. R. Solomon, S. A. Mabury, D. A. Ellis, B. F. Scott and D. C. G. Muir, Environ. Sci. Technol., 2000, 34, 274-281.

49 D. J. Bowden, S. L. Clegg and P. Brimblecombe, J. Atmos. Chem., 1998, 29, 85-107.

50 R. J. B. Peters, J. Environ. Monit., 2003, 5, 275-280.

51 S. Hashimoto, T. Azuma and A. Otsuki, Environ. Toxicol. Chem., 1998, 17, 798-805.

52 M. L. Hanson and K. R. Solomon, Environ. Pollut., 2004, 130, 371-383.

53 S. L. Herren-Freund, M. A. Pereira, M. D. Khoury and G. Olson, Toxicol. Appl. Pharmacol., 1987, 90, 183-189. 